\title{
Research on Blended Teaching Mode of College English Listening Class
}

\author{
Xue $\mathrm{Li}^{*}$ \\ School of Foreign Languages, Dalian Jiaotong University, Dalian, Liaoning 116028, China \\ *Corresponding author. Email: lixue_sherry@djtu.edu.cn
}

\begin{abstract}
With the rapid development of educational informatization, blended teaching integrates the advantages of traditional teaching and online teaching, which is more and more widely used in education. English listening has always been a weak link in the process of college English teaching. This paper starts with the current situation of college English listening teaching, analyzes the features and advantages of blended teaching mode, and discusses the new mode and method of college English listening teaching. The blended teaching mode of college English listening is established in order to further improve the quality and effect of college English listening teaching, optimize the learning environment for students, and achieve the best learning effect.
\end{abstract}

Keywords: Blended teaching, college English Listening teaching, advantage, teaching mode

\section{INTRODUCTION}

In the traditional classroom teaching, we are used to regard teachers as the main body of classroom teaching. The advantage is that it is convenient for teachers to effectively lead the classroom teaching activities, but it ignores the initiative of students, and we cannot teach according to students' aptitude. Different from traditional learning, internet learning not only has no time and space restrictions, but more importantly, students can reasonably choose suitable learning content and learning time according to their own situation in the process of internet learning, so as to fully mobilize their own subjective initiative. The blended learning mode combines the advantages of internet education and traditional classroom teaching, which not only leads to the subjectivity of learners' learning, but also gives play to the dominant role of teachers' teaching, which is conducive to the improvement of students' learning effect [1]. The application of blended learning in college English listening class will help students to achieve the real independent learning, improving their innovative spirit and the awareness and ability of learning with mobile learning devices.

\section{THE CURRENT SITUATION OF COLLEGE ENGLISH LISTENING TEACHING}

\subsection{Lack of Diversity in Learning Styles}

After entering the university, college students have not got rid of the inertia of traditional teaching and are still completely dependent on the school's teaching plan and traditional classroom teaching. However, this is obviously incompatible with the modern new environment of independent learning in the internet environment. As a result, college students cannot independently learn English listening, and they cannot get satisfaction from the learning of college English listening. Naturally, they have low interest in learning, which will inevitably affect the learning effect of the whole subject of college English. In addition, if students are only able to follow the teacher's explanation passively in class, and have no plan or arrangement for after-class learning, it is inevitable that they cannot establish their own personalized English knowledge framework and learning system, and naturally have no independent learning ability in English listening.

\subsection{Lack of Innovation in Teaching Mode}

At present, the rigid teaching model is prevalent in college English listening learning class, because universities do not pay attention to listening class, and teachers' profession quality is sufficient or the curriculum is arranged unreasonably. The listening class teaching is mainly based on the completion of exercises in the textbook. The teaching process is arranged according to three steps: listening to the tape, comparing the answers and explaining the exercises, which make students tend to get bored easily [2].

\subsection{Low Utilization Rate of Spare Time}

As listening ability requires a long and continuous training and accumulation process, if students have a high utilization rate of their spare time, the learning efficiency of college English listening will also be high. However, nowadays, most college students do not use their spare time well because they are free from the bondage of their parents and high school teachers. Many college students have not learned how to make personalized study plans for 
themselves, and it is not advisable to rely entirely on teachers' classroom teaching. Because the school's teaching arrangement must consider the average level of the vast majority of students, it cannot maximize the satisfaction of students' individual needs.

\subsection{Insufficient Utilization of Internet Recourses}

With the popularity of the network, online platforms can offer more and more channels and plentiful learning resources to provide help for students, but students cannot make effective use of them, why? It is not difficult to find the following reasons through the survey: firstly, there are too many resources available and all kinds of software on the internet, so students do not know how to screen; secondly, Many students feel very confused after doing listening exercises online, and they are not sure whether they can improve their English listening, which leads to the lack of success and loss of confidence; thirdly, students don't feel that they can get the teacher's guidance and help in time as they did in class.

\section{THE FEATURES OF BLENDED TEACHING MODE}

\subsection{Blended Learning}

Blended learning is to combine the advantages of traditional learning methods with the advantages of networked learning, which means that teachers can play a leading role in guiding, inspiring and monitoring the teaching process, and also fully reflect the participation, initiative, enthusiasm, interaction and creativity of learners in the learning process [3]. Traditionally, "blended learning" has been misinterpreted as a mixture of online and offline learning. The blending of learning forms is not the purpose of learning, but a means. The fundamental purpose of blended learning design is to promote the transformation of learners from knowledge cognition to cognitive behaviour, and to achieve the improvement of ability through continuous behaviour of reaching the standard. The blended learning method closely focuses on the learning objectives, and through the combination of face-to-face teaching, online learning, online and offline evaluation, action learning and other different methods and learning technologies, it can meet the requirements of students' continuous learning, so as to form a formative evaluation of learning effect and achieve the best learning effect.

\subsection{The Features of Blended Teaching Mode}

Compared with the traditional teaching mode, the blended teaching mode provides a rich choice in the communication mode. The Internet era has set up an alldimensional, multi-dimensional and three-dimensional learning space for learners, which makes the forms of communication more diverse and more effective [4]. Students can use a large number of learning resources on the network to freely choose the knowledge and content related to teaching. The Internet is a virtual space where students do not need to communicate with teachers face to face, which eliminates the psychological anxiety of students when learning foreign languages. Therefore, students can make use of the network platform to interact with teachers and students without any scruples, which is conducive to timely feedback on the content and effect of learning. After receiving the feedback information, the network platform can efficiently sort out the learning data of students, and the teachers can adjust the teaching content, key points and teaching progress accordingly. At the same time, unexpected thinking collisions may occur in the process of network communication, which is conducive to stimulating students' interest in learning English and better promoting the realization of independent learning. The establishment of blended teaching mode completely changes the traditional fixed mode of teaching materials and teachers' subjective explanation. Teachers can constantly adjust the teaching content to enrich and diversify the curriculum resources, which is of great help to teachers' scientific research in the later period.

\section{ADVANTAGES OF COLLEGE ENGLISH LISTENING BLENDED TEACHING MODE}

\subsection{Be Beneficial to Students}

Compared with the traditional classroom, blended learning is more flexible, learning in the network environment is more multi-dimensional, and the way of communication has changed accordingly. In traditional classroom teaching, teachers and students often communicate with each other through question and answer, while under the environment of blended teaching mode, students can use their notes to make their voices heard in class, gather the wisdom of the masses, and gradually build a trinity of student-notes, teacher-notes, teacher-students multi-way communication and feedback. In this way, the dominance of the class is returned to the students, which is conducive to stimulating the enthusiasm for learning and releasing the learning personality. Most of the students think, in blended learning mode, notes can not only help them accumulate vocabulary, pay attention to the key nodes in the process of the incident, familiar with the textual structure of "routine", also can know more clearly what happened in listening comprehension, understand the difficulties in where, the learning strategies in listening comprehension to have a more intuitive understanding. Compared with purely autonomous learning, blended learning has 
significantly stronger supervision over the listening process. With respect to students' willingness to study independently, teachers interspersed and intervened according to learning tasks, and the overlapping use of classroom and network platforms is conducive to expanding the depth and breadth of learning. To some extent, it helps learners avoid falling into the error of independent learning - free learning. Although teachers are invisible in the purely autonomous learning class and give students certain guidance after they lead the learning, the absence of the teacher's role in the class often makes students feel unable to adapt, and independent learning can easily evolve into free and aimless learning. On the whole, most students think it is necessary for teachers to provide interactive guidance and explanation. The main reason is that students have a weak sense of self-learning and a poor ability of independent learning. Most of the college students cultivated by the "cramming" teaching mode lack their due ability of independent learning and critical thinking [5].

\subsection{Be Beneficial to Teachers}

From the perspective of teachers, the advantage of blended learning also lies in that by transferring part of teaching time to the network platform, teachers can be liberated from the monotonous teaching process, have more class time to observe students' learning activities, and consciously change from the stereotyped teaching to interactive feedback teaching. At the same time, it puts forward higher requirements for teachers' professional quality, which is conducive to personal career growth. The note-taking method in the hybrid mode allows teachers to truly feel the learning difficulties faced by students from a broader perspective, fully realize the huge differences among learners, and make more appropriate adjustments to the teaching plan in time. The application of blended teaching mode in the new media era can encourage English teachers to update and change their original teaching concepts and ideas. The computer network technology in the new media era is changing every day; therefore, teachers need to use the advanced and effective teaching methods and means to adapt to the new teaching environment and changes, improving their own quality and advancing with the times. It is necessary to establish an environment which is conducive to the creative thinking for both teachers and students, so as to achieve the purpose of teaching and learning.

\subsection{Be Beneficial to Learning Environment}

College English listening blended teaching mode is mainly to combine the traditional teachers' classroom teaching, students' autonomous learning and internet auxiliary teaching, which can effectively expand and extend students' learning content beyond the classroom. While ensuring the students' ability to digest and absorb English listening knowledge, blended teaching can deepen its efficient application. Students can put what they've learned into practice. In this way, the true value of English listening learning can be realized, so as to give play to the auxiliary role of college English listening teaching.

\section{STRATEGIES OF ESTABLISHING BLENDED TEACHING MODE FOR COLLEGE ENGLISH LISTENING CLASS}

At present, China's higher education is transforming from exam-oriented education to elite education, qualityoriented education and mass education. The number of students in universities is increasing, and they tend to be multi-layered with great differences in personality [6]. Based on the information technology society, college education is facing new opportunities and challenges, and the application of the same English listening teaching model to students at different levels of education can no longer meet the needs of the current situation. The goal of carrying out English listening cooperative learning in blended mode is to promote students' autonomous learning ability, and to implement personalized teaching mode, giving full play to role of the internet that can carry out listening training repeatedly, impart listening skills and offer auxiliary teaching. Under the guidance of teachers, students can choose listening training content suitable for their learning progress according to their learning situation, knowledge level and main characteristics, and effectively use computer and network system to improve their listening ability and optimize the learning effect.

\subsection{Establish English Listening Blended Teaching Mode Based on Network Environment}

Under the network environment, English listening teaching should be based on students, taking listening practice as the main content, classroom teaching and internet-assisted teaching as the method. Classroom teaching still follows the traditional face-to-face teaching method of teachers, while web-based computer-aided teaching is mainly based on students' independent learning. At the same time, network teaching, as a supplement to classroom teaching, requires strict screening of its design and classroom content. Network listening teaching plays an inestimable role in improving students' English listening ability. The main training contents can be designed by teachers or designed and organized by students according to their own actual conditions. 


\subsection{Based on Classroom Instruction and Supplemented by Internet}

The full combination of teachers' classroom guidance and network assisted teaching makes college English listening teaching more three-dimensional and open. In addition, students discuss with each other in addition to classroom and network teaching to help other English learners is also an effective use of English listening. It is necessary for teachers to give proper guidance in classroom teaching and answer students' questions carefully. If the classroom teaching is abandoned, the students will lose their direction and goal in the internet-based independent teaching, which will lead to the serious decline of teaching quality. In addition, teachers should give students enough time to discuss in class, create an environment and platform for students to communicate, let students' different thoughts and ideas collide, deepen the impression of English listening learning, and complement and integrate with each other. Students put forward different ideas in the classroom, which can make up for the lack of communication between teachers and students to some extent.

\subsection{Teaching Methods}

The traditional teaching mode is to play the pronunciation of English training by the teacher and listen to the students. However, English listening teachers in the blended teaching mode are not only interpreters, guiders but also assistants. In the classroom teaching, teachers mainly teach learning and listening skills, so students can study and practice in a correct way, which will help students develop good learning habits. After class, teachers will upload the listening content to the network, and arrange the listening homework appropriately. After the students finish the after-class practice, they can use QQ, WeChat and other communicative tools to communicate with teachers or other students [7]. Teachers can guide and correct the mistakes.

\section{CONCLUSION}

There is no doubt that the traditional teaching mode has not kept pace with the development of the times, and the learning mode that relies entirely on school teaching arrangement and classroom teaching has become a thing of the past. Under the background of new media era, blended teaching mode, especially English listening and speaking course, students can take the initiative to integrate into the real English language environment, give full play to their subjectivity and creativity, think in English, and gradually improve their practical language ability in the atmosphere of listening and speaking practice. The blended teaching mode is not a simple combination of online learning and face-to-face classroom teaching, but to adhere to the teaching design as the core, to build a friendly teaching environment, to encourage students to play their role as the main body of the classroom. We should Establish a new teaching model that can adapt to the current internet environment, that is, " face-to-face instruction, self-study based, network guidance as a link". In a word, any teaching mode has its own advantages and disadvantages. The ultimate goal of the exploration and reform of teaching methods is to cultivate good learning habits and guide students to become qualified independent learners.

\section{REFERENCES}

[1] Zhou Yun, A Study on College English Smart Teaching Model from the Perspective of Mobile Internet, Modern Educational Technology, vol. 12, pp.79-85, 2016.

[2] Kuaibin and He Juan, Reflections on the Communicative Approach in College English Teaching, Course Education Research, vol.37, pp. 96-97, 2016.

[3] Hua Lulu, Chen Lin, Sun Mengmeng, Research on the Improvement of English Learning by Artificial Intelligence, Modern Distance Education, vol.6, pp.27, 2017.

[4] Michael Negnevitsky: Atificial Intelligence: A Guide to Intelligent System [M], Third Edition, Perason Education Limited, 2012.

[5]Bruton A, Samuda V., Learner and Teacher Roles in the Treatment of Error in Group Work, RELC Journal, vol. 11, pp. 49- 63, 1980.

[6] Wan Junya, The Role of Communicative Approach in College English Teaching Reform, Contemporary Education Research and Teaching Practice, vol.08, pp. 187-189, 2017.

[7] Cui He, Design and Research on Flipped Classroom Learning in College English Under the Background of "Internet + Education", Ability Wisdom, vol.1, pp.4, 2017. 